\title{
Upaya Diplomasi Pemerintah Indonesia Dalam Mediasi Konflik Kemanusiaan Di Myanmar
}

\author{
${ }^{1}$ Rio Sundari, ${ }^{2}$ Rendi Prayuda, ${ }^{3}$ Dian Venita Sary \\ ${ }^{123}$ Universitas Islam Riau \\ e-mail: riosundari@soc.uir.ac.id
}

\begin{abstract}
Abstrak
Penelitian ini bertujuan melihat upaya diplomasi pemerintah Indonesia dalam mediasi konflik kemanusiaan di Myanmar. Bertahun-tahun persekusi pemerintah Myanmar terhadap etnis Rohingya menjadi perhatian masyarakat internasional termasuk Indonesia. Indonesia memiliki kepentingan dalam konflik ini, selain sebagaiamana dari UUD 1945 dalam menjaga perdamaian dunia, isu konflik ini juga berada dalam kawasan Asia Tenggara yang jika tidak diselesaikan dengan cepat akan berpengaruh pada keamanan regional. Masalah pengungsi etnis Rohingya pada negara sekitarnya akan menjadi masalah baru bagi kawasan termasuk di Indonesia. Jumlah etnis Rohingya yang tewas dan mengungsi dikarenakan konflik ini hingga tahun 2019 selalu menunjukkan peningkatan yang signifikan. Penelitian ini menggunakan pendekatan model penelitian kualitatif deskriptif dalam melakukan analisis permasalahan secara empiris. Pendekatan kualitatif yang digunakan dalam penelitian ini adalah jenis studi kepustakaan yang sumber datanya dianalisis dari buku dan jurnal terkait penelitian upaya diplomasi pemerintah Indonesia dalam mediasi konflik kemanusiaan di Myanmar. Temuan dari penelitian ini menunjukkan bahwa ada beberapa strategi diplomasi yang dilakukan oleh Indonesia dalam masalah konflik etnis Rohingya dengan pemerintah Myanmar, yakni pengajuan proposal kemanusiaan dan usulan formula 4+1 bagi masyarakat rohingya dimasa depan. Kemudian, Indonesia juga memanfaatkan OKI sebagai organisasi Islam internasional terbesar untuk menekan dan mendesak Myanmar segera menyelesaikan kekerasan terhadap etnis Rohingya. Terakhir, diplomasi dalam bentuk menyediakan bantuan logistic bagi etnis Rohingya dan partisipasi masyarakat Indonesia dalam menyuarakan penyelesaian konflik di Myanmar dengan media massa secara masif.
\end{abstract}

Kata Kunci: Diplomasi, Rohingya, Mediasi, Pengungsi

\begin{abstract}
This study aims to examine the diplomatic efforts of the Indonesian government inmediating humanitarian conflicts in Myanmar. For years the Myanmar government's persecution of the Rohingya ethnicity has caught the attention of the international community, including Indonesia. Indonesia has an interest in this conflict, apart from being the mandate of the 1945 Constitution in maintaining world peace, the issue of this conflict is also in the Southeast Asia region which if not resolved quickly will affect regional security. The problem of Rohingya refugees in surrounding countries will be a new problem for the region, including Indonesia. The number of Rohingya who have died and fled due to this conflict until 2019 has always shown a significant increase. This study uses a descriptive qualitative research model approach in analyzing the problems empirically. The qualitative approach used in this research is a type of literature study whose data sources are analyzed from books and journals related to research on diplomatic efforts by the Indonesian government in mediating humanitarian conflicts in Myanmar.The findings of this study indicate that there are several diplomatic strategies carried out by Indonesia in the problem of the Rohingya ethnic conflict with the Myanmar government, namely submitting humanitarian proposals and proposing a $4+1$ formula for the Rohingya community in the future. Then, Indonesia also took advantage of the OIC as the largest international Islamic organization to pressure and urge Myanmar to immediately resolve violence against the Rohingya ethnicity. Finally, diplomacy in the form of providing logistical assistance for the Rohingya ethnicity and the participation of the Indonesian people in voicing the resolution of the conflict in Myanmar with the mass media.
\end{abstract}

Keyword: Diplomacy, Rohingya, Mediation, Refugees

P-ISSN 1693-3516 | E-ISSN 2528-7575 


\section{PENDAHULUAN}

Pasca Perang Dingin, dunia mengalami transformasi konflik yang signifikan. Awalnya konflik didominasi oleh negara-negara yang berporos kepada ideologi Liberal oleh Amerika Serikat dan ideology Komunis oleh Uni Soviet. Namun, ketika kekuatan Uni Soviet runtuh dan Amerika Serikat keluar sebagai pemenang dan menjadi kekuatan tunggal dunia, konflik justru semakin kompleks dan menyebar hampir di seluruh dunia. Berbagai bentuk dan aktor yang memicu konflik bermunculan, bahkan konflik terlihat lebih menakutkan dan berbahaya. Orientasi konflik semakin bias karena sejak runtuhnya kekuatan Uni Soviet, konflik internal negara justru menjadi masalah baru yang tidak terelakkan. Jika perseteruan Amerika Serikat dan Uni Soviet yang membentuk dunia menjadi bipolar (dua kutub kekuatan dunia) terlihat jelas, justru konflik internal pasca Perang Dingin menjadi lebih sulit karena negara dihadapkan pada konflik dengan warga Negaranya sendiri. Artinya, negara bukan lagi berseteru dengan negara lain, tetapi negara berada pada posisi menyakiti, membunuh bahkan menggenosida masyarakat yang secara sah adalah warga Negaranya sendiri. Diaspora konflik bukan hanya menimpa negara berkembang dan baru merdeka, namun juga terjadi di negara yang secara ekonomi dan politik mumpuni.

Konflik internal pemerintah Myanmar dengan suku Muslim Rohingya adalah salah satu dari sekian banyak bentuk tragedy yang mematikan dan memilukan. Bahkan Perserikatan Bangsa-Bangsa (PBB) mengatakan bahwa etnis Rohingya adalah etnis yang paling tertindas di dunia. Salah satu laporan dari MSF (Medecins Sans Frontieres), yakni sebuah lembaga yang beranggotakan para Aktivis Kemanusian Dokter Lintas Batas menunjukkan bahwa pada tahun 2017 saja sekitar 647.000 etnis Rohingya mengungsi ke negara Bangladesh untuk menyelamatkan diri dari persekusi yang dilakukan oleh militer Myanmar dan sekitar 6.700 orang meninggal dunia dalam konflik berdarah ini. Dari 6.700 yang meninggal, 69,4\% meninggal karena ditembak, 8,8\% meninggal karena dibakar, 5\% meninggal karena dipukuli, 2,6\% meninggal setelah kekerasan seksual, dan sisanya ada yang meninggal karena disembelih lehernya dan diculik (https://www.bbc.com/indonesia/dunia-42351386). Secara lengkap ditunjukkan table berikut pada rentang waktu dari tahun 1991 hingga tahun 2019.

\section{Tabel 1.}

Data Korban PersekusiPemerintah Myanmar terhadapSuku Rohingya

\begin{tabular}{lll}
\hline Tahun & Status & Jumlah(Orang) \\
\hline $1991-1992$ & MelarikanDiridari Myanmar & 260.000 \\
\hline 2001 & Tewas & 10 \\
\hline $2008-2009$ & MengungsidenganTujuan Malaysia dan Thailand & 6.000 \\
\hline 2012 & Tewas & 410 \\
\hline & Mengungsi & 140.000 \\
\hline 2014 & Tewas & 200 \\
\hline & Mengungsi & 87.000 \\
\hline 2015 & Didugakuburansuku Rohingya & 139 \\
\hline 2016 & Mengungsi & 143.500 \\
\hline 2017 & Tewas & 1.100 \\
\hline & Mengungsi & 230.000 \\
\hline 2018 & Tewas & 10.000 \\
\hline 2019 & Mengungsi & 620.000 \\
\hline
\end{tabular}


Tabulasi data ini menunjukkan indikasi kekerasan begitu masif yang terjadi pada etnis Rohingya. Data ini merupakan survei yang dilakukan oleh beberapa lembaga internasional seperti MSF, PBB, International Development Committee, International Crisis Group, dan lainnya (Mohajan, 2018). Artinya, survey ini tidak mendata secara keseluruhan korban karena keterbatasan informasi. Maka, menurut MSF, etnis Rohingya yang menjadi korban jauh lebih banyak dari perkiraan data tersebut.

Penderitaan suku Muslim Rohingya ini tentu berimplikasi pada situasi keamanan regional Asia Tenggara. Perjalanan berbahaya melarikan diri keluar dari Myanmar menuju negara-negara sekitarnya menjadi masalah baru bagi negara yang disinggahi. Bangladesh, Malaysia, Thailand dan Indonesia yang menjadi negara terdekat dengan Myanmar tentu akan kebanjiran pengungsi orang Rohingya (Singh, Bilveer: 2014). Kehadiran pengungsi Rohingya tentu akan menjadi sebuah dilemabagi negara-negara Asia Tenggara terutama negara yang menjadi persinggahan mereka. Di satu sisi menerima pengungsi adalah salah satu bentuk kemanusiaan, namun di sisi lain kehadiran pengungsi akan menjadi masalah baru bagi internal negara mereka. Kondisi inilah yang menjadi masalah krisis kemanusiaan terhadap orang Rohingya sulit untuk diselesaikan, sehingga tahun hingga saat ini konflik ini belum dapat terselesaikan secara tuntas.

Krisis ini mendapat kritikan dari berbagai negara dan organisasi internasional yang fokus pada krisis kemanusian. ASEAN (Association of Southeast Asian Nations)sebagai organisasi regional di Asia Tenggara yang diharapkan mampu menyelesaikan konflik di Myanmar juga belum bias berbuat banyak. Hal ini karena ASEAN tersandera oleh doktrin dan prinsip tidak saling mengintervensi (non-interference principle) urusan internal masing-masing negara yang harus dihormati (Limsiritong, 2018).

Begitu juga organisasi Islam terbesar dunia seperti OKI (Organisasi Kerjasama Islam) tahun 2012 mengusulkan untuk mengirim tim pencari fakta terkait pembantaian orang Rohingya. Meskipun tim pencari fakta ini pada tahun tersebut di izinkan untuk menyelidiki kasus ini, masalah persekusi ini hingga beberapa tahun setelahnya tetap terjadi dan korban tetap berjatuhan (Singh, Bilveer, Ibid). Maka, posisi Indonesia sebagai pemimpin organisasi regional Asia Tenggara ASEAN sekaligus sebagai negara dengan populasi muslim terbesar dunia memiliki peran penting dalam menyelesaikan konflik ini secara serius atas nama kemanusiaan. Ketika upaya intervensi ASEAN sudah tidak mampu menembus solusi konflik di Myanmar, maka tentu upaya diplomasi Indonesia dibutuhkan dalam menyelesaikan masalah ini.

\section{METODE}

Penelitian ini menggunakan pendekatan model penelitian kualitatif deskriptif dalam melakukan analisis permasalahan secara empiris. Pendekatan kualitatif yang di gunakan dalam penelitian ini adalah jenis studi kepustakaan yang sumber datanya dianalisis dari buku dan jurnal terkait penelitian upaya diplomasi pemerintah Indonesia dalam mediasia konflik kemanusiaan di Myanmar. Selanjutnya data dianalisis secara induktif dengan cara mengumpulkan berbagai artikel yang relevan dengan penelitian ini. Tahapan berikutnya adalah memberikan kesimpulan dari hasil penelitian yang menjadi temuan dalam penelitian ini.

\section{HASIL DAN PEMBAHASAN}

Masalah kemanusiaan yang menimpa etnis Rohingnya bukannya masalah baru, justru ini merupakan catatan krisis kemanusiaan yang terjadi jauhs ebelum negara Burma berganti nama menjadi Myanmar. Artinya tulisan dan penelitian yang dilakukan oleh peneliti terkait konflik dan krisis kemanusiaan ini begitu banyak. Seperti tulisan dari Mohamad Rosyidin dalam tulisannya yang berjudul 
Why Collective Identity matters: Constructivism and the Absence of ASEAN's Role in the Rohingya Crisis, dalam tulisan ini Rosyidin lebih melihat pertimbangan konstruksi kolektif ASEAN dalam membuat sebuah kebijakan sebagai jalan penyelesaian konflik Rohingya. Rosyidin menawarkan kontribusi konstruktivisme dalam mendiagnosa kebijakan ASEAN. Menurutnya, negara-negara ASEAN seharusnya lebih membangun prioritas pada proses identitas kolektif dalam melihat konflik Rohingya, sehingga konflik bias diselesaikan dengan peran badan organisasi regional tersebut. Namun, dikarenakan tidak adanya prioritas identitas kolektif di antara Negara negara ASEAN, maka hingga saat ini tidak ada satu kebijakan ASEAN yang mengarah kepada penyelesaikan konflik Rohingya (Rosyidin, 2017).

Berbeda dengan tulisan Mahanam Bhattacharjee Mithun yang berjudul Ethnic Conflict and Violence in Myanmar: The Exodus of Stateless Rohingya People, tulisan ini lebih focus kepada mengungkapkan alasan utama di balik konflik etnis yang terjadi di wilayah Rakhine dan pemaksaan terhadap etnis Rohingya untuk keluar dari wilayah Myanmar secara besar-besaran (Mithun, 2018). Tulisan Nehginpao Kipgen yang berjudul The Rohingya Crisis: the Centrality of Identity and Citizenship, lebih focus kepada perkembangan eksodus pengungsi Rohingya secara besar-besaran ke Bangladesh. Tulisan ini lebih menganalisis perjanjian antara Myanmar dan Bangladeh terkait rencana pemulangan pengungsi etnis Rohingya. Menurutnya, masalah identitas dan status kewarganegaraan Rohingya adalah isu yang fundamental yang harus diselesaikan oleh otoritas pemerintah Myanmar (Kipgen, 2019).

Afroza Anwary dalam tulisannya yang berjudul Interethnic Conflict and Genocide in Myanmar, memaparkan bahwa konflik yang terjadi di Myanmar adalah bentuk genosida sebagai akibat dari kebijakan militer pemerintah Myanmar yang disengaja. Isu identitas kolektif penduduk Myanmar yang digunakan oleh militer Myanmar di jadikan sebagai alat untuk mengusir dan menggenosida penduduk minoritas etnis Rohingya yang dianggap sebagai penduduk ilegal dan beda identitas. Stigma ini sengaja dibangun untuk menggenosida minoritas yang notabene berbeda identitas dengan mayoritas penduduk Myanmar (Anwary, 2020).

Analis konflik lain seperti Naufal Armia Arifin, dengan judul tulisannya ASEAN's Role in Mitigating the Risk of Rohingya Radical ization lebih focus kepada analisis kajian mengenai penerimaan negara-negara ASEAN terhadap pengungsi etnis Rohingya. Namun, dalam tulisan ini juga Naufal memaparkan munculnya masalah keamanan baru regional yang akan mengancam keamanan negaranegara ASEAN. Hal ini karena kekhawatiran terhadap kelompok radikal yang bias mempengaruhi masyarakat Rohingya yang mengungsi di negara-negara ASEAN. Tentu ini akan menjadi masalah baru bagi negara penerima pengungsi. Oleh karena itu muncul ini siatif mendirikan dan menguatkan tiga pilar ASEAN yang salah satunya berkaitan dengan menjaga keamanan regional (Armia Arifin, 2016). Berbeda dengan tulisan Irawan Jati dengan judul Comparative Study of the Roles of ASEAN and the Organization of Islamic Cooperation in Responding to the Rohingya Crisis, yang lebih mengelaborasi jalan diplomasi yang dilakukan oleh ASEAN dan Organisasi Kerjasama Islam (OKI). Tulisan ini mencoba memberikan komparasi dalam upaya penanganan konflik etnis Rohingya dengan melihat agenda yang dilakukan oleh OKI yang merupakan pilihan yang dilakukan sebab melihat ASEAN tidak memberikan solusi yang berarti dalam penyelesaian konflik tersebut (Jati, 2017).

Berbeda dengan Deasy Silvia Sari dkk dalam tulisannya yang berjudul Indonesian Government Policy on Rohingya Refugees, yang lebih focus kepada bagaimana kebijakan yang dilakukan oleh pemerintah Indonesia terhadap pengungsi etnis Rohingya yang menyelamatkan diri dari persekusi yang dilakukan oleh negaranya. Tulisan ini melihat dari perubahan sikap Indonesia terkait pilihan kebijakan yang sulit. Awalnya Indonesia menolak menerima pengungsi Rohingya, namun adanya tuntutan masayarakat lokal dan internasional terhadap pemerintah Indonesia mampu mengubah sikap untuk bias menerima pengungsi etnis Rohingya (Pratisti et al., 2019).

Beberapa penelitian yang dilakukan oleh analis yang berkaitan dengan konflik Rohingya di atas sebagian besar terfokus pada bagaimana dampak konflik antara pemerintah Myanmar dan etnis Rohingya. 
Perbincangan hanya seputar bagaimana kegagalan ASEAN sebagai organisasi regional dalam menyelesaikan konflik ini. Kemudian ada beberapa peneliti fokus pada jalan diplomasi Myanmar dan Bangladesh dalam menyelesaikan konflik dengan perantara penyelesaian status kewarga negaraan etnis Rohingya yang juga tidak terselesaikan hingga saat ini. Maka, ada satu kajian yang belum tersentuh oleh penggiat dan pemerhati konflik di Myanmar ini yakni terkait dengan upaya pemerintah Indonesia dalam menjembatani upaya penyelesaian konfliksektarian di Myanmar tersebut. Kajian dalam perspektif peran Indonesia terhadap masalah konflik Myanmar penulis anggap sangat diperlukan mengingat bahwa Indonesia adalah negara dengan mayoritas penduduknya adalah beragama Islam yang tentu saja tidak boleh diabaikan oleh pemerintah Indonesia. Hal ini terkait dengan menjaga keutuhan system politik domestic supaya terjaga dan berjalan dengan baik, maka aspirasi mayoritas penduduk Indonesia harus diwadahi oleh negara.

Usaha dalam menjalin hubungan dengan negara lain diperlukan capaian kepentingan nasional yang dapat ditunjang dengan identitas diri dan citra positif. Suatu Negara perlu melakukan diplomasi sebagai saranan dalam memenuhi kepentingan nasionalnya dan mengatasi permasalahan yang ada. Suatu capaian kepentingan tidak akan lepas dari perubahan lingkungan strategis baik dalam tatanan regional maupun global yang memberikan kesempatan sekaligus tantangan bagi proses pencapaian kepentingan tersebut (Nurika, 2017). Dalam inisiatif mempromosikan negara dan mengingkatkan eksistensi serta menyebarkan pengaruh ke negara lain tentu akan meraih kepentingan nasional bagi negara. Caranya adalah menggunakan diplomasi.

Diplomasi semula berasal dari bahasa Yunani yaitu Diploun/Diploma yang memiliki arti menggandakan (duplikasi). Definisi diplomasi sendiri dapat diartikan sebagai perpaduan antara ilmu dan seni perundingan dalam menyampaikan maksud dan tujuan dalam suatu pertemuan resmi yang diwakilkan oleh utusan suatu negara (Djelantik, 2008).Diplomasi adalah suatu praktek dalam hubungan intenasioanl antar negara melalui perwakilan resmi yang meliputi seluruh proses hubungan luar negaeri dan formasi kebijakan. Sejatinya diplomasi adalah usaha untuk menyakinkan pihak atau negara lain untuk dapat memahami pandangan dan membenarkan perspektif kita tanpa perlu menggunakan kekerasan. Sebagi salah satu alat utama yang digunakan negara dalam pelaksanaan politik luar negeri diplomasi dapat menjadi suatu nilai tawar (state branding) untuk membangun image sebuah Negara. Tujuan diplomasi bagi Negara ialah guna mengamankan integritas politik, territorial dan menjaga kepentingan dan keamanan nasional (Fadli, 2016). Fungsi utama pelaksanaan diplomasi melahirkan negosiasi dengan menyelesaikan perbedaan serta menajmin kepentingan Negara melalui sarana dan efektivitas negosiasi yang tepat sebagai ruang lingkupnya. Diplomasi merupakan konsep yang menciptakan negosiasi sebagai praktiknya. Diplomasi yang sukses membutuhkan negosiasi yang efektif, apabila negosiasi gagal maka dampaknya berupa terciptanya konflik/ perang yang juga merupakan bagian dari sarana diplomasi. Karena dalam sejarahnya Prinsip fundamental dari realisme klasik adalah hubungan internasional terpisah dari pandangan politik dalam negeri. Oleh karena itu proses politik internasional dapat bersifat anarkis.

Identifikasi dasar dari pandangan ini adalah sebuah perjuangan dengan dua mekanisme yang tersedia, yaitu: perang dan diplomasi. Menurut Hans Morgenthau, pelaksanaan urusan luar negeri suatu negara oleh para diplomatnya adalah untuk kekuatan nasional dalam perdamaian strategi dan taktik militer oleh para pemimpin militer untuk kebijakan nasional dalam perang. Bagi Morgenthau, diplomasi bukan konstitutif hubungan internasional. Hal itu merupakan sesuatu yang harus dimiliki seorang aktor untuk mempertahankan kedaulatannya dari ancaman. Pada dasarnya diplomasi yang dimaksud disini hanyalah teknik, karena pada prinsipnya dalam memahami politik erat hubungannya dengan "kepentingan yang didefinisikan dalam hal kekuasaan (power)".

Terdapat tiga cara dasar dalam pelaksanaan diplomasi negara yaitu Persuaian, Kerjasama dan Pertentangan (Prayuda \& Sundari, 2019). Diplomasi mencakup lima hal yang berbeda namun signifikan 
yaitu; Politik Luar Negeri, Negosiasi, Mekanisme Negosiasi, Interpretasi Keahlian Seseorang yang melakukan negosiasi, dan Tujuan Negosiasi. Diplomasi secara umum terbagi dua, yaitu;

(1) Soft Diplomacy, yaitu diplomasi yang dilakukan dalam bentuk penyelesian secara damai dalam bidang ekonomi, budaya, bahasa dan persahabatan. Cara ini terbukti memiliki pengaruh yang signifikan, melihat banyak negara yang lebih senang memahami budaya asing. Biasanya soft diplomacy ini tendensinya melakukan pendekatan dengan mengikuti perundingan bilateral seperti diplomasi publik yang bertujuan untuk memberikan pemahaman sikap, institusi dan kebijakan yang tepat untuk diambil oleh negaranya(Hennida, 2009) atau dengan cara menyelesaikan permasalahan dengan menyertakan pihak ketiga sebagai penengah yaitu Mahkamah Internasional.

(2) Hard Diplomacy, yaitu diplomasi yang dilakukan dalam bentuk memamerkan kekuatan militernya dengan cara seperti agresi militer atau dalam bentuk yang lebih ekstrim yaitu "Perang". Negara juga dapat terlibat kerja sama pertahanan dengan negara lain yang gunanya untuk meningkatkan efektivitas serta efek deterrence apabila terjadi konflik.

Terdapat pola-pola diplomasi (Djelantik, 2016), yaitu;

a. Diplomasi Bilateral yang diartikan sebagai hubungan antara dua pihak dalam membahas apa yang menjadi kepentingan nasional. Biasanya dalam diplomasi ini, terdapat prinsip hubungan timbal balik, jadi ketika suatu negara membutuhkan bantuan, maka di lain hari ia juga akan memberikan sesuatu yang dibutuhkan oleh negara lain. Namun terkadang terdapat imbalance of power dimana terdapat ketimpangan antara negera lemah dan negara kuat dalam melakukan diplomasi tersebut.

b. Diplomasi Multilateral, yaitu interaksi antara tiga atau lebih negara yang memiliki common interest and common goals. Biasanya diplomasi ni dilakukan secara terbuka dan melalui negosiasi agar mendapat kepercayaan lebih dari lingkungan internasional. Keunggulan lain dari diplomasi multilateral adalah kemungkinan terciptanya kebijakan yang mendapatkan legitimasi kuat karena mengikutsertakan banyak negara.

c. Diplomasi Personal, yaitu diplomasi yang dilakukan seperti melakukan kunjungan kepresidenan kenegara lain atas urusan negara maupun pribadi diluar pekerjaan sebagai diplomat dan organ politik namun pemikirannya dapat mempengarui insting personal negara yang dikunjunginya.

d. Summit Diplomacy, yaitu jenis diplomasi konferensi yang digunakan oleh global governance dimana kepala negara bertemu tatap muka untuk bernegosiasi secara langsung. Misalnya kehadiran negara berdaulat dan memilki kekuatan dalam pembentukan PerserikatanBangsaBangsa (PBB). Diplomasi ini biasanya bersifat tingkat tinggi.

e. Diplomasi Asosiasi, yaitu diplomasi yang dilakukan karena adanya kesamaan kepentingan dnasional dengan negara yang menjalin hubunnga diplomasi bersama. Biasanya pola ini membentuk sebuah organisasi yang memberikan pengaruh terhadap sistem dan tatanan politik global dan regional serta didalamnya membahas isu-isu mengenai permasalahan yang terjadi. Contohnya ialah ASEAN (Association of Southeast Asian Nations) yang merupakan organisasi Asia Tenggara dengan tujuan membangun institusi regional sebagai alternatif penyelesaian sangketa dan memperkuat solidaritas kawasan regional.

f. Diplomasi Konferensi, yaitu diplomasi yang menyangkut pihak-pihak yang berkepentingan sehingga berkumpul dalam satu pertemuan dan konferensi untuk membahas mengenai isu-isu serta mencari dan menyepakati solusi demi penyelesaian konflik atau kesenjangan tersebut. Pola ini lebih menekankan komunikasi secara lisan atau dengan cara face-to-face. Hasil dari diplomasi konferensi akan berjalan dengan efektif hanya jika mencapai konsensus.

\section{Diplomasi Indonesia untuk Myanmar dalam 3 Jalur}

Konflik terkait isu kemanusiaan di Myanmar yang menimpa etnis Rohingya telah menarik keprihatinan banyak masyarakat internasional juga masyarakat Indonesia. Sebagai negara yang juga 
berpengaruh di Kawasan Asia Tenggara, Indonesia telah melakukan aksi strategis untuk membantu penanganan konflik di negara Myanmar. Upaya untuk menyelesaikan konflik tersebut dibutuhkan kompleksitas dan keterlibatan banyak piihak. Menariknya, masyarakat Indonesia menilai isu Rohingya merupakan isu agama (Mahmood et al., 2017). Meski tidak sepenuhnya salah, reduksi konflik mengarah pada permasalahan agama sama sekali tidak tepat. Meski demikian, Kepedulian Indonesia dalam misi diplomasinya membantu penyelesaian konflik di Myanmar dengan paradigma kemanusiaan yang universal bukan terkotak dalam identitas tertentu. Selama ini Indonesia telah mengupayakan usaha untuk turut menyelesaikan konflik Rohingya namun selalu saja terkendala pada prinisi non-intervensi. Sakralitas prinsip ini sepenuhnya di pegang teguh oleh negara-negara anggota ASEAN, sebab prinsip ini bertujuan untuk menjaga stabilitas keamanan kawasan. Namun, tentu saja perlu adanya rasa kepedulian terlebih apabila terjadi isu kekerasan dan pelanggaran HAM (Hak Asasi Manusia) yang dinilai cukup berat. Dilema ini disadari oleh negara Indonesia, untuk itu pemerintah akhirnya turut membantu menyelesaikan konflik dengan menempuh jalur diplomasi (Rosyid, 2019).

Terdapat 3 track (Jalur) diplomasi yang telah ditempuh sejauh dengan realitas yang ada bagi Indonesia dalam upaya penyelesaian kasus, yaitu pertama, Pemerintah sebagai aktor pencipta perdamaian melalui diplomasi. Level diplomasi dilakukan oleh pemerintah dalam menghadapi kriris terutama dalam kasus high politics karena biasanya dalam perumusan diperlukan adanya power. Asumsi dasar diplomasi dalam skala internasional adalah relative power yang artinya Politik disuatu negara (Indonesia) harus mampu mengontrol, mengintervensi bahkan mempengaruhi negara lain. Dalam hal ini, diplomasi Indonesia dalam menangani konflik di Myanmar terkait etnis Rohingya adalah:

a. Indonesia melakukan pendekatan secara personal terhadap pemerintahan Myanmar dengan pola diplomasi Government to Government dengan usulan agar Pemerintah Myanmar secepatnya menyelesaikan konflik etnis tanpa diskriminasi. Karena sejatinya, konflik tersebut telah termasuk kategori pelanggaran HAM berat.

b. Indonesia terus mendorong keterlibatan ASEAN sebagai komunitas regional atas keberadaannya di kawasan Asia Tenggara untuk mendukung pemerintah Myanmar dalam upaya menyelesaikan konflik.

c. Mendirikan Kamp-Kamp bagi pengungsi Rohingya, serta memberikan hibah senilai 7,5 miliar untuk membantu repartiasi Refugee's Rohingya dari Cox's Bazar, Bangladesh. (Utara et al., 2018).

d. Pemenuhan kebutuhan Dasar Pengungsi Rohingya dari bantuan teknis dan psikis yaitu, (1) Membantu pemenuhan bahan makanan dan penampungan sementara pengungsi Rohingya, Myanmar di Aceh pada tahun 2009. (2) Menampung 63 pengungsi di Aceh Timur dan 121 pengugsi di Lhoksumawe pada tahun 2013. (3) Bersama UNHCR (United Nations High Commissioner for Refugees) dan IOM (International Organization for Migration) menyediakan obat, penampungan, dan pangan bagi 1.345 warga Rohingya serta Membangun Sarana Pendidikan bagi remaja dan anakanak senilai 1 juta Dollar USA di Rakhine pada tahun 2015. (4) Mengirim 115 Ton makanan, selimut, dan sarung bagi Masyarakat pada 2016. (5) dan Rencana pembagunan IHC / Indonesia Health Center, di desa Myaung Bywe (Utami, Saleh, \& Oktafiani, 2018).

e. Disela-sela KTT / Konferensi Tingkat Tinggi pada April 2017 di Manila. Presiden Indonesia melakukan penyampaiannya dalam komitmen Indonesia membantu Myanmar dalam program kerjasama inklusif yang kemudian dilanjutkan dengan rehabilitasi bersama AKIM/ Aliansi Kemanusiaan Indonesia Untuk Myanmar dalam program HASCO / Humanitarian Assistance for Sustainable Community (Landry \& Tupetz, 2018).

Kedua, aktor diplomasi bukan hanya negara akan tetapi juga non-negara atau organisasi yang juga sebagai pencipta perdamaian dan resolusi konflik melalui diplomasi. Tujuan dari jalur kedua ini adalah membantu upaya penyelesaian dengan meningkatkan pemahaman komunikasi dan kolaborasi. Dengan begitu aktor non-negara mampu mengetahui akar permasalahan dan dapat mengeksplor problem solving 
secara kompleks tanpa adanya keberpihakan dari negara manapun. Indonesia ikut berperan dalam meredakan konflik yang terjadi di Myanmar dengan mengutus representatif yaitu menteri luar negeri untuk menemui Aung Sang Suu Kyi untuk menyampaikan amanah masyarakat Indonesia dalam pengajuan Proposal Kemanusiaan dan Usulan Formual 4+1 bagi masyarakat rohingya dimasa depan yakni dengan kebijakan (1) Pengembalian status stabilitas dan keamanan internal kawasan, (2) Perlindungan kepada seluruh masyarakat terutama di Rakhine tanpa keberpihakan dan memandang ras, (3) Menahan diri, (4) Membuka akses kemanusian, kemudian (5) Menyepakati bahwa Indonesia beserta ASEAN terlibat dalam penyaluran bantuan kemanusiaan. (Setiawan \& Hamka, 2020).

Terkait pada track kedua ini, mekanisme penyaluran bantuan kemanusiaan dipimpin oleh pemerintah Myanmar sendiri yang melibatkan komisi ICRC / International Committee of the Red Cross sebagai aktor non-negara melainkan Organisasi Internasional dalam membantu capaian isi Kementerian Luar Negeri Republik Indonesia dan perhatian masyarakat Indonesia atas konflik yang terjadi di Myanmar. Selain itu adanya peluncuran AKIM/ Aliansi Kemanusiaan Indonesia-Myanmar pada 31 Agustus 2017 Silam dengan prioritas bantuan pada 4 hal yakni, Kesehatan, Pendidikan, Ekonomi, dan Teknis (Kennedy \& McCoy, 2017). Bertujuan untuk mendapatkan akses dalam mekanisme bantuan kemanusiaan dan mengintervensi otoritas Myanmar agar segera mengatasi krisis/konflik tersebut.Kemudian Indonesia dalamhubunganinternasionalnyaikutserta pada organisasikemanusiaanyaitu OKI/ Organisasi Kerjasama Islam. Dalam penanganan konflik ini OKI memiliki peran sebagai inisiator dan sebagai fasilitator pendesak negara anggota organisasi untuk turut serta mencegah kekerasan. OKI bersama Indonesia yang juga termasuk perwakilan anggota ASEAN memiliki mekanisme untuk menghentikan pelanggaran HAM terhadap minortitas Rohingya dengan member bantuan kamp-kamp pengungsi bagi korban konflik. (Beyrer\& Kamarulzaman, 2017).

Ketiga, Penggerakan Publik untuk memberikan perhatian lebih terhadap kasus Rohingya dengan pola inisiatif dan interaktif pemberitaan antar media. Tugas dan peran masyarakat internasional tidak boleh terlepas begitu saja sebab isu kemanusiaan tumbuh dan berkembang di kalangan masyarakat itu sendiri. Selain masyarakat sebagai obejek perlindungan, masyarakat juga berhak untuk ikut berpartisipasi dalam upaya kemanusiaan. Pada era modern ini, beragam respon muncul dan etis media yang berusaha unntuk turut terlibat dalam membawa perubahan di kehidupan masyarakat. Maka, solusi damai untuk memperjuangkan nilai-nilai kemanusiaan memicu media massa Indonesia semakin tampil sebagai garda terdepan untuk mengekspose peristiwa kemanusiaan dan pelanggaran HAM di Myanmar. Dari Media Massa ini, masyarakat Indonesia melakukan demonstrasi dan membuat gerakan hastag save rohingya di seluruh sosial media. Media membantu kedua pihak yang berkonflik untuk mengungkapkan kebenaran substansial dibalik konflik tersebut. Diploomasi kemanusiaan yang dilakukan oleh Indonesia merupakan bagian dari diplomasi yang melibatkan partisipasi public karena masyarakat Indonesia memandang masalah Rohingya sebagai bagian masalah etnis muslim, dilihat pula Indonesia merupakan mayoritas muslim terbesar. Sehingga seakan ada kepedulian akibat kesamaan etnis dan nilai pragmatis, masyarakat Indonesia melalui media turut menyuarakan hakata swarga Rohingya tersebut.

\section{Prinsip Kebijakan Luar Negeri Bebas - Aktif dalam Diplomasi mengatasi Konflik}

Indonesia sendiri memegang prinsip kebijakan luar negeri bebas-aktif sejak awal kemerdekaan. Keberadaan ilustrasi prinsip kebijakan Bebas-Aktif menunjukkan tindakan yang dilakukan oleh Indonesia dalam upaya penyelesaian kasus terkait konflik Rohingya dengan Alternative Diplomacy. Prinsip BebasAktif juga memungkinkan Indonesia untuk mencari kepentingan nasional tanpa keberpihakan terhadap kubu tertentu serta tetap mengupayakan kepentingan nasional yang pada hal tersebut telah tertuang dalam Undang-Undang. (Rzulfadasmagmailcom, 2017).

Berdasarkan dari penjelasan diatas, kepentingan Indonesia dalam penyelesaian konflik Rohingya tetap dijadikan prioritas. Meskipun terdapat ancama internal bagi Indonesia seperti, biaya penampungan 
pengungsi dari Rohingya yang cukup besar dan biaya teknis lain, namun Indonesia juga mempunyai kepentingan untuk turut menjaga perdamaian dunia yang termaktub pada prinsip diplomasi Indonesia yang Bebas-Aktif. Prinsip tersebut secara tidak langsung telah berperan sebagai norma dalam interaksi internasional dan mengatasi permasalahan krusial baik yang mengancam keamanan dan stabilitas nasional maupun regional. Atas dasar prinsip tersebut, diplomasipun dilakukan dengan melalui cara persuasif yang sesuai pada kondisi dan situasi yang terjadi seperti ; (1) Pengajuan proposal Kemanusiaan, (2) Melakukan dialog dan tatap muka $G$ to Gatau Government to Government. (3) Pemberian bantuan kemanusiaan langsung, dan (4) Turut bergabung pada organisasi Internasional dalam mengatasi permasalahan/konflik. (Matthew, 2020).

Prinsip politik Bebas dan Aktif sendiri menjamin keberadaan Indonesia dalam membantu komunitas Rohingya, Myanmar tanpa harus menunjukkan keberpihakan antara pihak manapun serta tanpa bersikap ofensif kepada pemerintah Myanmar. Selain itu, kepedulian pemerintah Indonesia atas penderitaan yang dialami etnis Rohingya di Myanmar akibat dari kearogansian pemerintah Myanmar memberikan upaya riil bagi pemenuhan kebutuhan hidup pengungsi Rohingya di Indonesia dengan nilainilai pragmatisnya.

\section{KESIMPULAN}

Konflik yang terjadi antara etnis Rohingya dengan pemerintah Myanmar adalah salah satu konflik yang sulit untuk diselesaikan. Selain karena prinsip non intervensi sesame negara ASEAN yang tertera di dalam piagam ASEAN, Myanmar juga menutup diri dari intervensi negara lain di dalam urusan negaranya. Atas dasar inilah, Indonesia menggunakan berbagai pendekatan diplomasi baik pada level formal $G$ to $G$ (Government to Government) baik antara Indonesia dengan pemerintah Myanmar, antara Indonesia dengan OKI maupun dengan jalur kemanusiaan melalui bantuan logistic untuk etnis Rohingya. Upaya Diplomasi yang dilakukan Indonesia dalam menghentikan konflik vertical ini.

Tidak bias dipungkiri bahwa konflik ini tidak mudah untuk diselesaikan dengan waktu singkat. PBB saja menyatakan bahwa konflik ini termasuk satu di antara konflik yang mematikan dan masif. Hal ini terbukti sejak konflik ini terjadi hingga saat ini belum terselesaikan hingga tuntas. Berbagai upaya sedang dilakukan oleh negara-negara dalam menghentikan konflik ini. Indonesia mengagendakan konflik ini menjadi salah satu focus kebijakan luar negeri, hal ini karena selain sebagai negara paling besar dan paling berpengaruh di ASEAN, juga salah satu bentuk kepeduliaan terhadap isu kemanusiaan.

\section{SARAN}

Masalah ini harusnya menjadi perhatian PBB sebagai organisasi terbesar di dunia. Sebenarnya PBB bias melakukan tekanan kepada Myanmar atas dasar pelanggaran HAM berat. Dengan sanksi-sanksi yang bias dilancarkan PBB sebagai perwakilan negara di dunia, masalah ini bias terselesaikan. Sanksi bias diberikan terutama sanksi ekonomi yang sudah terbukti manjur ketika beberapa negara melanggar hokum internasional, sanksi ini mampu menjadikan negara tersebut menghentikan pelanggaran tersebut. Indonesia juga pernah diancam oleh internasional atas isu pelanggaran HAM sehingga dengan ancaman tersebut Indonesia mulai mengubah strategi kebijakan luar negerinya bahkan salah satu sebab Indonesia akhirnya meratifikasi sebagai negara yang anti terhadap pelanggaran HAM.

Penulis menyadari masih banyak kekurangan dalam penelitian ini terkait data dan konflik yang masih belum mampu diselesaikan. Maka penelitian lanjut terkait isu ini sangat direkomendasi untuk diteliti sebagai penambah khasanah keilmuan. 


\section{DAFTAR PUSTAKA}

[1] Anwary, A. (2020). Interethnic Conflict and Genocide in Myanmar. Homicide Studies, 24(1), 85-102. https://doi.org/10.1177/1088767919827354

[2] Armia Arifin, N. (2016). ASEAN's Role in Mitigating the Risks of Rohingya Radicalization. Jurnal Hubungan Internasional $\square$ Tahun IX, 1, 67-80.

[3] Beyrer, C., \& Kamarulzaman, A. (2017). Ethnic cleansing in Myanmar: the Rohingya crisis and human rights. The Lancet, 390(10102), 1570-1573. https://doi.org/10.1016/S0140-6736(17)32519-9

[4] Djelantik, S. (2008). Praktik Diplomasi Teori antara Praktik. Yogyakarta: Graha Ilmu.

[5] Fadli. (2016). Film The Radi I Sebagai Sarana Diplomasi Kebudayaan. 2003.

[6] Hennida, C. (2009). Diplomasi Publik dalam Politik Luar Negeri. Masyarakat, Kebudayaan Dan Politik, Vol. 22, 17-23.

[7] Jati, I. (2017). Comparative Study of the Roles of ASEAN and the Organization of Islamic Cooperation in Responding to the Rohingya Crisis. IKAT: The Indonesian Journal of Southeast Asian Studies, 1(1), 17. https://doi.org/10.22146/ikat.v1i1.27466

[8] Kennedy, J., \& McCoy, D. (2017). WHO and the health crisis among the Rohingya people of Myanmar. The Lancet, 389(10071), 802-803. https://doi.org/10.1016/S0140-6736(17)30507-X

[9] Kipgen, N. (2019). The Rohingya crisis: The centrality of identity and citizenship. Journal of Muslim Minority Affairs, 39(1), 61-74. https://doi.org/10.1080/13602004.2019.1575019

[10] Landry, M. D., \& Tupetz, A. (2018). Disability and the Rohingya Displacement Crisis: A Humanitarian Priority. Archives of Physical Medicine and Rehabilitation, 99(10), 2122-2124. https://doi.org/10.1016/j.apmr.2018.06.005

[11] Limsiritong, N. (2018). Why ASEAN Fails to Play Role in the Rohingya Situation from the Perspective of ASEAN Charter. Asian Political Science Review, 1(2), 73-79. https://doi.org/10.12778/235108617x15452339029761

[12] Mahmood, S. S., Wroe, E., Fuller, A., \& Leaning, J. (2017). The Rohingya people of Myanmar: health, human rights, and identity. The Lancet, 389(10081), 1841-1850. https://doi.org/10.1016/S0140-6736(16)00646-2

[13] Matthew, G. (2020). Kepentingan Nasional Indonesia dan Diplomasi ala Indonesia Dalam Penyelesaian Konflik Rohingya. Jurnal Hubungan Internasional, 13(1), 75. https://doi.org/10.20473/jhi.v13i1.17655

[14] Mithun, M. B. (2018). Ethnic conflict and violence in Myanmar: The exodus of stateless rohingya people. International Journal on Minority and Group Rights, 25(4), 647-663. https://doi.org/10.1163/15718115-02504003 
[15] Mohajan, H. K. (2018). The Rohingya Muslims in Myanmar are Victim of Genocide! ABC Journal of Advanced Research, 7(2), 95-108. https://doi.org/10.18034/abcjar.v7i2.82

[16] Nurika, R. R. (2017). Peran Globalisasi di Balik Munculnya Tantangan Baru Bagi Diplomasi di Era Kontemporer. Jurnal Sosial Politik, 3(1), 126. https://doi.org/10.22219/sospol.v3i1.4404

[17] Pratisti, S. A., Hidayat, T., \& Sari, D. S. (2019). When Solidarity is Trampled by Religious Sentiment: Outlining Indonesian Muslim Solidarity toward Rohingya Refugees. Jurnal Ilmu Sosial Dan Ilmu Politik, 23(1), 1. https://doi.org/10.22146/jsp.35732

[18] Prayuda, R., \& Sundari, R. (2019). Diplomasi dan Power: Sebuah Kajian Analisis. Journal of Diplomacy and International Studies, 02(1), 80-93.

[19] Rosyid, M. (2019). Peran Indonesia Dalam Menangani Etnis Muslim Rohingya Di Myanmar. Jurnal Hukum \& Pembangunan, 49(3), 613. https://doi.org/10.21143/jhp.vol49.no3.2190

[20] Rosyidin, M. (2017). Why collective identity matters: Constructivism and the absence of ASEAN's role in the rohingya crisis. Asia-Pacific Social Science Review, 17(1), 52-65.

[21] Rzulfadasmagmailcom, E. (2017). Jurusan Ilmu Hubungan Internasional - Prodi Ilmu Hubungan Internasional Fakultas Ilmu Sosial dan Ilmu Politik Universitas Riau Kampus Bina Widya Jl. H.R. Soebrantas Km. 12,5 Simp. Baru Pekanbaru 28293. 5, 1-11.

[22] Setiawan, A., \& Hamka, H. (2020). Role of Indonesian Humanitarian Diplomacy toward Rohingya Crisis in Myanmar. June 2017. https://doi.org/10.4108/eai.5-11-2019.2292481

[23] Sing, Bilveer. 2014. Tantangan Orang Rohingya Myanmar. Yoyakarta: Gadjah Mada University Press.

[24] Utami, D. W., Saleh, R., \& Oktafiani, I. (2018). Indonesia's Constitutional Immigration Policy: A Case of Rohingya Ethnic Group Refugees. Journal of Indonesian Social Sciences and Humanities, 8(2), 119-132. https://doi.org/10.14203/jissh.v8i2.84

[25] Utara, U. S., Utara, U. S., \& Utara, U. S. (2018). Peran Indonesia dalam Memberikan Bantuan Kepada Etnis Rohingya di Perbatasan Bangladesh.

[26] Bbc, (2017), diaksesdari<https://www.bbc.com/indonesia/dunia-42351386> pada tanggal 28 Juli 2019, pukul 13.35 WIB. 